\title{
The Influence of Political Trust and Social Trust on the Political Participation of Villagers: Based on the Empirical Analysis of 974 Samples in 10 Provinces
}

\author{
Ying Chen \\ School of Public Administration, Jinan University, Guangzhou, China \\ Email: 17817716190@163.com
}

How to cite this paper: Chen, Y. (2018) The Influence of Political Trust and Social Trust on the Political Participation of Villagers: Based on the Empirical Analysis of 974 Samples in 10 Provinces. Open Journal of Social Sciences, 6, 235-248. https://doi.org/10.4236/jss.2018.66021

Received: May 14, 2018

Accepted: June 26, 2018

Published: June 29, 2018

Copyright $\odot 2018$ by author and Scientific Research Publishing Inc. This work is licensed under the Creative Commons Attribution International License (CC BY 4.0).

http://creativecommons.org/licenses/by/4.0/

\begin{abstract}
Based on 974 sample data from 24 townships in 10 provinces, the impact of political trust and social trust on villagers' political participation was analyzed. The study finds that the overall political trust of the villagers is significantly positively related to political participation. Among them, the villagers' trust in the Party Central Committee and the township government has the strongest interpretation of their political participation. Social trust has no impact on the villagers' political participation, general trust and special trust. There is no statistical significance in political participation with the villagers. That is, general trust and special trust have no statistical significance for the villagers' political participation.
\end{abstract}

\section{Keywords}

Political Trust, Social Trust, The Political Participation of Villagers

\section{Introduction}

As one of the most common political behaviors, political participation is an important indicator of the country's political modernization [1]. China's peasant population accounts for more than half of the total population. Farmers' political participation has an important impact on the development of political modernization in China. It also measures the primary indicators of grassroots democracy and villagers' autonomy.

The political participation of villagers is the focus of academic research in recent years. According to the influence factors of villagers' political participation, 
scholars have put forward a number of explanatory variables, but the basic identity and trust is one of the important variables. Trust is the core concept of social capital theory. It has always played an important role in related research at home and abroad. Trust includes political trust and social trust. Both of them directly affect the government's governance ability and governance level [2], has an important role in the political participation of citizens. Then, under the current background of village self-government, what is the political trust and social trust status of the villagers, and what are their impacts on political participation? Which of the villagers' political trust and social trust has a greater influence on political participation? This is also the question that this article will answer.

\section{Literature Review and Research Hypothesis}

\subsection{Influence of Political Trust on Political Participation}

Political trust is generally considered to be a positive political psychology, and is based on the positive behavior and relationships that arise from the interaction between citizens and the political system. Political trust generally refers to citizens' beliefs or confidence that the political system or government's output is consistent with their expected results [3] [4]. There are certain differences between China and the West in their understanding of political trust, but they all believe that the core meaning of political trust lies in "belief and dare to entrust and expect" [5], that citizens' political trust is a source of government legitimacy. Scholars such as Mishler and Rose divided political trust into two aspects: culture and institution [6].

At present, the academic community has made a qualitative or quantitative study on the relationship between political trust and political participation, and believes that there is a direct or indirect relationship between the two. Putnam indirectly stated in his book "Making Democracy Work" that trust and participation as social capital influence each other; According to Norris, the public with low level of trust in the government is more passive in assessing their distance from the government, and has a lower perception of the effectiveness of political participation, and the voting behavior is not very positive either [7]. Gamson find that political mistrust can directly affect non-institutionalized political participation of residents, such as resistance to the government and participation in protests [8]. Domestic scholars have also done relevant research on the relationship between the two, but there are still some differences in the conclusions. Sun and others found that an important factor in whether villagers participate in the election of village committees is their degree of political trust in the grass-roots party committees and governments of the township [9]. Zheng cuts in from the perspective of political psychology and finds that political trust has a positive effect on policy through empirical research. Participating satisfaction has a significant positive predictive effect [10]. Fu [11] also found a significant positive correlation between villagers' political trust and political participation. However, some scholars have found that there is only a weak correlation 
between the villagers' trust in the village committee and the township government and their participation in the election of the village committee [12]. Shi T. found through empirical research that villagers' political understanding, political participation, and dissatisfaction with village committees will increase their tendency to participate in elections. That is to say, villagers do not trust village committees but will increase their enthusiasm for participating in elections [13]. The reasons for these disagreements are diverse, such as the researchers' methods of collecting data and sample sizes, the inconsistent measurement of political participation, and the different levels of political trust measurement. In this study, a representative nationwide sample was used to include villagers' participation in the village committee election as the most direct institutionalized political participation as a variable. The villagers participate in the village committee. Election was used to measure political participation and political trust. The dimensions include the central government to the township level. Political trust has an enhanced effect on the dynamics of public participation in politics. The enthusiasm of villagers to participate in political activities, the more distrust the government, the more indifferent the villagers are to political activities.

Based on the above discussion, we can research hypothesis 1: The villagers' political trust is significantly and positively related to political participation.

\subsection{The Impact of Social Trust on Political Participation}

Putnam believes that social trust is the degree of mutual trust between citizens, and is an important component of social capital [14]. Social trust can be divided into two aspects: general trust and special trust. Generally speaking, general trust refers to the trust between individuals who have little contact with individuals, meet people in peace, and strangers. Special trust refers to the trust of individuals in close-knit groups, such as relatives and friends. Uslaner's behavior of general trust has an ethical basis, reflects the perception of the ethical community of citizens and is therefore more important than special trust [15]. Studies have shown that the higher the degree of social trust, the easier the mutual benefit and cooperation between people, and the higher the level of social governance [16]. At present, scholars at home and abroad have produced more fruitful results in the operation and measurement of social trust. However, research on the relationship between social trust and political participation, especially on rural social trust, seems rather inadequate.

As far as the relationship between social trust and political participation is concerned, scholars' research findings are slightly different, but overall there is a positive correlation between them. In a society with a high level of social trust, people tend to prefer association based on mutual trust, and organized members are more willing to participate in political activities. Domestic and foreign scholars generally use the broad concept of social capital to measure political participation, which greatly increases the complexity and ambiguity of social trust interpretation. In a study that separates social trust from social capital, Edlin et al. 
studied that when voters vote, they often consider not only the impact of election results on their own welfare, but also the impact of election results on other voters [17]. This kind of altruism tends to be influenced by many factors, and social trust is one of them. Domestic scholars Xing and Luo found positive correlation between the level of social trust and the probability of residents participating in the voting through empirical research [18]. Tang's research on national survey data found that on a personal level, general social trust is conducive to residents' formation of democratic concepts and values, and promotes residents' participation in regular political activities [19]. However, Sun and others found that social trust does not have a significant relationship with whether villagers participate in the village committee election [9]. At present, China's research on the relationship between social trust and political participation is mainly in the cities. There is still relatively little research on rural social trust and political participation, and political trust and social trust are analyzed in the same analytical framework. The study of villagers' political participation is even more lacking.

Based on the above discussion, hypothesis 2 of this study is proposed: villagers' social trust and political participation are significantly positively related.

\section{Second, Data, Variables and Analysis Methods}

\subsection{Data}

The data in this study were obtained from the database of "China Township Democracy and Governance Survey" hosted by Professor Maof Nankai University and Wang of the University of Nottingham. This project is a social survey on the development and governance of grassroots democracy in China. The data collection time was from July 2008 to April 2011. The sample selection covers 24 townships in 10 provinces or municipalities. Used non-probability sampling methods to sample villagers, selected 2 - 3 administrative villages for each township, conduct a comprehensive survey of households in each village, and finally obtain 2221 effective questionnaires. The questionnaires included information such as village demographics and socio-economic characteristics, evaluation of government functions, political participation, trust, and democratic appraisal. Based on the research questions of this study, only village demographic and socio-economic characteristics and trust were selected. And political participation data. After the data was obtained, the data was preprocessed, and the invalid data such as "not knowing", "do not want to answer" were deleted, the missing data was averaged and, finally, 974 valid samples were obtained.

The description of all variables and their descriptive statistics are shown in Table 1.

\subsection{Independent Variables}

The independent variables of this study include control variables and explanatory variables, and the control variables include population variables and 
Table 1. Variable description and descriptive statistics.

\begin{tabular}{|c|c|c|c|c|c|}
\hline Variable & Variable Assignment & Mean & $\begin{array}{c}\text { Std. } \\
\text { Deviation }\end{array}$ & Max & Min \\
\hline $\begin{array}{l}\text { Party Committee and } \\
\text { Government of Centre }\end{array}$ & Completely distrust $=1$, less trust $=2$, more trust $=3$, very trust $=4$. & 3.579 & 0.615 & 4 & 1 \\
\hline $\begin{array}{l}\text { Party Committee and } \\
\text { Government of Province }\end{array}$ & Completely distrust $=1$, less trust $=2$, more trust $=3$, very trust $=4$. & 3.154 & 0.626 & 4 & 1 \\
\hline $\begin{array}{l}\text { Party Committee and } \\
\text { Government of County }\end{array}$ & Completely distrust $=1$, less trust $=2$, more trust $=3$, very trust $=4$. & 2.962 & 0.683 & 4 & 1 \\
\hline $\begin{array}{l}\text { Party Committee and } \\
\text { Government of Township }\end{array}$ & Completely distrust $=1$, less trust $=2$, more trust $=3$, very trust $=4$ & 2.860 & 0.781 & 4 & 1 \\
\hline Trust in Family & Completely distrust $=1$, less trust $=2$, more trust $=3$, very trust $=4$. & 3.767 & 0.471 & 4 & 1 \\
\hline Trust in Relatives & Completely distrust $=1$, less trust $=2$, more trust $=3$, very trust $=4$. & 3.525 & 0.576 & 4 & 11 \\
\hline Trust in Friends & Completely distrust $=1$, less trust $=2$, more trust $=3$, very trust $=4$. & 3.399 & 0.628 & 4 & 1 \\
\hline Trust in Strangers & Completely distrust $=1$, less trust $=2$, more trust $=3$, very trust $=4$. & 1.832 & 0.706 & 4 & 1 \\
\hline Trust in Business Partners & Completely distrust $=1$, less trust $=2$, more trust $=3$, very trust $=4$. & 2.636 & 0.738 & 4 & 1 \\
\hline Trust in Most People in Society & Completely distrust $=1$, less trust $=2$, more trust $=3$, very trust $=4$. & 2.501 & 0.725 & 4 & 1 \\
\hline Political Participation & No $=0$, Yes $=1$ & 0.64 & 0.481 & 1 & 0 \\
\hline Gender & Male $=1$, female $=2$ & 1.422 & 0.494 & 2 & 1 \\
\hline Nationalities & Han $=1$, minority $=2$ & 1.080 & 0.237 & 2 & 1 \\
\hline Age Group & $18-29=1,30-39=2,40-49=3,50-59=5,60$ and above $=5$ & 2.549 & 1.15587 & 5 & 1 \\
\hline Religious Beliefs & $\begin{array}{l}\text { Christianity }=1, \text { Buddhism }=2 \text {, Islam }=3 \text {, Taoism }=4, \\
\text { Folk religion }=5 \text {, Other religions }=6 \text {, No }=7\end{array}$ & 6.322 & 1.6908 & 4 & 1 \\
\hline Political Landscape & $\begin{array}{l}\text { CCP members }=1, \text { CYL members }=2, \text { Democrats }=3, \\
\text { Non-partisan }=4\end{array}$ & 3.192 & 1.1747 & 4 & 1 \\
\hline Family Annual Income (yuan) & $\begin{array}{l}1000 \text { or less }=1,1000 \text { to } 2000 \text { yuan }=2,2000 \text { to } 4000 \text { yuan }=3,4000 \text { to } \\
6000 \text { yuan }=4,6000 \text { to } 10,000 \text { yuan }=510,000 \text { to } 20,000 \text { yuan }=6 \text {, } \\
20,000 \text { to } 30,000 \text { yuan }=7,30,000 \text { to } 40,000 \text { yuan }=8,40,000 \text { to } 60,000 \\
\text { yuan }=9,60,000 \text { to } 100,000 \text { yuan }=10 \text {. }\end{array}$ & 6.098 & 2.0201 & 10 & 1 \\
\hline Current Educational Level & $\begin{array}{l}\text { Primary school and below }=1 \text {, junior high school }=2 \text {, high school }=3 \text {, } \\
\text { junior college }=4 \text {, major school }=6 \text {, master's degree and above }=6\end{array}$ & 2.272 & 1.011 & 6 & 1 \\
\hline
\end{tabular}

socioeconomic variables. Population variables include villagers' gender, ethnicity, age group and religious beliefs; socio-economic variables, family annual income and education level. The explanatory variables are the villagers' trust, which is further divided into two aspects: political trust and social trust. Among them, the indicators of political trust include the trust level of the party committees and governments from the central government to the township level. Through a measure of the trust of the Party Central Committee and the government, the trust of provincial party committees and governments, the trust of county party committees and governments, and the trust of local township Party committees and governments, a more comprehensive analysis of villagers' levels The level of trust of the government; Social trust includes general trust and special trust. In the questionnaire, trust in relatives, trust in one's own family, trust in good friends, trust in strangers, trust in business partners Degree and the de- 
gree of trust of most people in society are measured in six aspects. All the answers to measure trust are divided into complete distrust, less trust, comparative trust, and very trust, and they are assigned 1 to 4 respectively.

From Table 1 and Table 2, we can see that in terms of political trust, the villagers in China have the highest degree of trust in the central government, with an average of 3.579. The ratio of trust and trust is as high as $95 \%$, followed by the provincial government. The degree of trust, with an average of 3.154, the ratio of more trust and very trust is $\mathbf{8 8 . 3 \%}$, and the average level of trust is lowest for the governments and party committees at the township level, but the trust ratio also reached $71.2 \%$. It can be seen that the level of political trust of Chinese villagers is relatively high, which verifies the empirical research conclusions of Chinese scholars. The phenomenon that the villagers' political trust is inversely proportional to the government hierarchy presented in the table is consistent with the research of Li Lianjiang and other scholars [20], This may be because the villagers have more contact with the grass-roots government, and it is easier to assess the performance of the grass-roots government. The higher the level, the more difficult the government to assess.

According to Table 3, we can see that in terms of social trust, $98.6 \%, 96.8 \%$, and $96.7 \%$ of the villagers who have more trust and very trust in family members, relatives, and friends. There are 59.7\%, 53.1\%, and $14.2 \%$ of the villagers who more trust and very trust the business partners, most of the people in society, and strangers.

A simple calculation of the average value in Table 1 shows that the average level of social trust of the villagers in China is 2.943 , and the average level of political trust is 3.139 , which shows that the level of political trust of the villagers is generally higher than the level of social trust. It also shows that the level of political trust in the countryside and the level of social trust are generally higher.

\subsection{Dependent Variables}

The dependent variable of this study is political participation. Political participation is a complex concept. In terms of form, it includes institutionalized participation and non-institutional participation. At present, the domestic research on

Table 2. Villagers' political trust.

\begin{tabular}{cccccc}
\hline Level & $\begin{array}{c}\text { Completely } \\
\text { Distrust }\end{array}$ & Less Trust & More Trust & Very Trust & Number \\
\hline $\begin{array}{c}\text { Party Committee and } \\
\text { Government of Centre }\end{array}$ & $0.8 \%$ & $4.2 \%$ & $31.2 \%$ & $63.8 \%$ & 974 \\
$\begin{array}{c}\text { Party Committee and } \\
\text { Government of Province }\end{array}$ & $0.5 \%$ & $11.2 \%$ & $60.7 \%$ & $27.6 \%$ & 974 \\
$\begin{array}{c}\text { Party Committee and } \\
\text { Government of County }\end{array}$ & $2.2 \%$ & $18.8 \%$ & $59.8 \%$ & $19.3 \%$ & 974 \\
$\begin{array}{c}\text { Party Committee and } \\
\text { Government of Township }\end{array}$ & $4.8 \%$ & $23.9 \%$ & $51.6 \%$ & $19.6 \%$ & 974 \\
\hline
\end{tabular}


Table 3. Villagers' social trust.

\begin{tabular}{cccccc}
\hline Target & $\begin{array}{c}\text { Completely } \\
\text { distrust }\end{array}$ & Less trust & More trust & Very trust & Number \\
\hline Trust in family & $0.4 \%$ & $0.9 \%$ & $20.2 \%$ & $78.4 \%$ & 974 \\
Trust in relatives & $0.4 \%$ & $20.9 \%$ & $40.6 \%$ & $56.2 \%$ & 974 \\
Trust in friends & $0.7 \%$ & $5.5 \%$ & $46.8 \%$ & $49.9 \%$ & 974 \\
Trust in business partners & $6.0 \%$ & $34.2 \%$ & $50.2 \%$ & $9.7 \%$ & 974 \\
$\begin{array}{c}\text { Trust in most } \\
\text { people in society }\end{array}$ & $8.4 \%$ & $38.4 \%$ & $47.8 \%$ & $5.3 \%$ & 974 \\
Trust in strangers & $32.9 \%$ & $53.0 \%$ & $12.4 \%$ & $1.8 \%$ & 974 \\
\hline
\end{tabular}

political participation activities focuses on two types of behaviors: election participation and protest behavior. The participation of villagers in village committee elections is the most important political participation of villagers, and it is also the most important manifestation of institutionalized political participation. This study uses participating elections to reflect the dependent variables, and the corresponding question in the survey questionnaire "Have you recently participated in the voting of the village committee owner (that is, the village chief) or the election of the deputies to the National People's Congress?", required the villager to choose between "not participating" and "participating". The value of "Yes" is 0 , and the value of "No" is 1 . The results of descriptive statistics show that the participation rate of the villagers was $63.8 \%$, which is more than $95 \%$ of the figures announced by the Ministry of Civil Affairs in 2013. This shows that the political participation of the villagers, especially election participation, is not an official announcement of optimism and mobilizes villagers' politics. The enthusiasm for participation is an important task for promoting grassroots democracy.

\subsection{Analysis Method}

In this study, SPSS 22.0 data analysis software was used to analyze the correlation between control variables and trust variables. The results showed that the correlation between the two variables is not high or there is no correlation, so trust can be used as an independent Explanatory variable. Secondly, the principal component analysis of the explanatory variables was performed, relevant factors were extracted and named. Finally, build a statistical analysis model. Model 1 only considers control variables and political trust variables to test hypothesis 1 , model 2 only considers control variables and social trust to verify hypothesis 2 , and model 3 adds social trust and political trust on the basis of control variables to compare the two impacts of political participation. Since the dependent variable of this study is a binary variable, all models were analyzed using Logistic Binary Regression.

\section{Research Findings and Analysis}

Trust is a kind of subjective emotion, political trust and social trust belong to 
two dimensions of trust, they will influence each other, so it is difficult to independently test the influence on political participation. In this study, we used principal component analysis (PCA) to extract factors of trust before regression comparison. As shown in Table 4, the factor analysis extracted three factors: political trust, general trust and special trust, and excluded the collinearity caused by multiple independent variables.

From the empirical results in Table 4, we can see that the "P" value of nationality, age group, religious beliefs, family income, and education level in the control variables are all less than 0.05 , which is significantly related to villagers' political participation. There is a significant positive correlation between ethnicity, age group, religion and family income and villagers' political participation, indicating that older people are more willing to participate in the election of village committees; the higher the income, the higher the willingness of villagers to participate in politics. This may be due to high income. The villagers are more capable of meeting the political demands; as to why the positive relationship between ethnic groups and religions and political participation remains to be further studied. The coefficient of educational level in the table is negative, indicating that the less the villagers with higher education level engage in political participation activities, which is different from the research results of most Chinese scholars, but it is in line with the Western democratic society represented by Bahry and Silver. In related research, they have studied that there is a positive correlation between participation in elections in the West and the level of education, but in the communist countries it is found that the level of education is

Table 4. Factor analysis of trust.

\begin{tabular}{cccc}
\hline & Political trust & General trust & Special trust \\
\hline $\begin{array}{c}\text { The level of trust in provincial party committees } \\
\text { and provincial governments }\end{array}$ & 0.704 & 0.201 & -0.396 \\
$\begin{array}{c}\text { The level of trust in the county party committee } \\
\text { and county government }\end{array}$ & 0.730 & 0.276 & -0.434 \\
$\begin{array}{c}\text { The level of trust in township party committees } \\
\quad \text { and governments }\end{array}$ & 0.690 & 0.318 & -0.331 \\
$\begin{array}{c}\text { The level of trust in the party central committee } \\
\text { and the central government }\end{array}$ & 0.579 & -0.031 & -0.208 \\
$\quad \begin{array}{c}\text { The level of trust in family } \\
\text { The level of trust in relatives }\end{array}$ & 0.564 & -0.600 & 0.077 \\
$\quad \begin{array}{c}\text { The level of trust in friends } \\
\text { The level of trust in strangers }\end{array}$ & 0.604 & -0.567 & 0.168 \\
$\begin{array}{c}\text { The level of trust in business partners } \\
\text { The level of trust in most people in society }\end{array}$ & 0.599 & -0.483 & 0.275 \\
$\quad$ Variance contribution & 0.260 & 0.510 & 0.509 \\
& 0.460 & 0.248 & 0.564 \\
\hline
\end{tabular}

Note: the principal component analysis selects the variables whose eigenvalue is greater than 1 and concludes that the KMO value is equal to 0.748 Bartlett's sphericity check chi-square value is 3138.748 and the significance is 0.00 . It is suitable for factor analysis. 
negatively related to political participation [21]. Because when the election is a form of formalism, the higher the level of people with culture, the less enthusiasm for participation. Among the control variables, there is no statistical significance for the political participation of villagers in terms of political status. Domestic research generally believes that the identity of party members is significantly positively related to political participation, which is quite different from the findings of this study. This may be due to the fact that the sample data of the Unsatisfactory, only $14.6 \%$ of party members, $85.2 \%$ of non-party members, the correlation effect is not good. The influence of gender on political participation varies with explanatory variables, but overall there is no correlation or too little correlation. This may be due to the fact that women's status in China has been improved and women's political consciousness has been continuously awakened. There is less difference in political participation.

Table 5 shows that the political trust factor of villagers in model 1 has statistical significance for political participation $(\mathrm{P}<0.01)$ and the regression coefficient is positive. It shows that villagers with a higher level of political trust are more willing to participate in political activities. This is in line with the hypothesis. Among them, the villagers' level of political trust increases the probability of villagers participating in political activities by $34.6 \%$. It can be seen that political participation has a greater impact on villagers' political participation. From model 2, it can be seen that after controlling variables such as age, income, and gender, general trust and special trust factors are not significant for villagers' political participation, indicating that they have little impact on villagers' political participation. Hypothesis 2 cannot be used. Model 3 is to compare two kinds of trust in order to reduce errors. Based on the control variables, it also adds political trust and social trust factors. It is found that political trust is still significantly positively related to villagers' political participation, and the correlation coefficient changes little. The two factors of social trust still have no effect on the villagers' political participation. It is clearly demonstrated that there is no correlation or low correlation between social trust factors and villagers' political participation. In contrast, political trust has a greater impact on villagers' political participation.

Since social trust is not related to the political participation of villagers, the two dimensions of social trust are not further discussed in terms of their impact on political participation, and the influence of villagers' trust on political participation by party committees and governments at all levels is continuously observed. Based on the control variables, the trust degrees of the central, provincial, county, township party committees, and governments were incorporated into the model one by one, corresponding to model 4 , model 5 , model 6 , and model 7, respectively. From the four models, it can be seen that the villagers' level of trust in the four levels of government has a significant impact on political participation. Except for provincial party committees and the government, the level of trust is significant at $\mathrm{P}<0.05$, and the remaining three levels of government are all at $\mathrm{P}<0.01$ was significant, and the regression coefficients were 
Table 5. Return of political and social trust to political participation.

\begin{tabular}{|c|c|c|c|c|c|c|c|}
\hline & Model 1 & Model 2 & Model 3 & Model 4 & Model 5 & Model 6 & Model 7 \\
\hline \multicolumn{8}{|l|}{ Control variable } \\
\hline Gender & $\begin{array}{c}-0.279^{\star} \\
(0.149)\end{array}$ & $\begin{array}{l}-0.177 \\
(0.149)\end{array}$ & $\begin{array}{c}-0.259^{*} \\
(0.151)\end{array}$ & $\begin{array}{l}-0.208 \\
(0.148)\end{array}$ & $\begin{array}{l}-0.204 \\
(0.147)\end{array}$ & $\begin{array}{l}-0.250^{*} \\
(0.148)\end{array}$ & $\begin{array}{c}-0.297^{\star *} \\
(0.150)\end{array}$ \\
\hline Nationalities & $\begin{array}{l}0.798^{* *} \\
(0.355)\end{array}$ & $\begin{array}{l}1.021^{* * *} \\
(0.352)\end{array}$ & $\begin{array}{l}0.818^{* *} \\
(0.356)\end{array}$ & $\begin{array}{l}0.952^{* * *} \\
(0.353)\end{array}$ & $\begin{array}{c}0.939^{* * *} \\
(0.352)\end{array}$ & $\begin{array}{l}0.881^{* *} \\
(0.353)\end{array}$ & $\begin{array}{l}0.826^{* *} \\
(0.355)\end{array}$ \\
\hline Age group & $\begin{array}{l}0.504^{* * *} \\
(0.075)\end{array}$ & $\begin{array}{l}0.544^{* * *} \\
(0.074)\end{array}$ & $\begin{array}{c}0.499^{* * *} \\
(0.075)\end{array}$ & $\begin{array}{l}0.493^{* * *} \\
(0.075)\end{array}$ & $\begin{array}{c}0.528^{* * *} \\
(0.074)\end{array}$ & $\begin{array}{c}0.524^{* * *} \\
(0.075)\end{array}$ & $\begin{array}{c}0.517^{* * *} \\
(0.075)\end{array}$ \\
\hline Religious beliefs & $\begin{array}{l}0.112^{\star * *} \\
(0.042)\end{array}$ & $\begin{array}{l}0.118^{\star * *} \\
(0.041)\end{array}$ & $\begin{array}{c}0.113^{\star * *} \\
(0.042)\end{array}$ & $\begin{array}{l}0.123^{\star * *} \\
(0.042)\end{array}$ & $\begin{array}{l}0.117^{\star *} \\
(0.041)\end{array}$ & $\begin{array}{c}0.113^{\star * *} \\
(0.042)\end{array}$ & $\begin{array}{l}0.109^{* * *} \\
(0.042)\end{array}$ \\
\hline Political landscape & $\begin{array}{l}-0.04 \\
(0.072)\end{array}$ & $\begin{array}{l}-0.063 \\
(0.071)\end{array}$ & $\begin{array}{l}-0.046 \\
(0.072)\end{array}$ & $\begin{array}{l}-0.069 \\
(0.072)\end{array}$ & $\begin{array}{l}-0.061 \\
(0.071)\end{array}$ & $\begin{array}{l}-0.047 \\
(0.072)\end{array}$ & $\begin{array}{l}-0.041 \\
(0.072)\end{array}$ \\
\hline $\begin{array}{l}\text { Family annual income } \\
\text { (yuan) }\end{array}$ & $\begin{array}{c}0.107^{* * *} \\
(0.037)\end{array}$ & $\begin{array}{l}0.108^{* * *} \\
(0.037)\end{array}$ & $\begin{array}{c}0.106^{* * *} \\
(0.037)\end{array}$ & $\begin{array}{c}0.111^{* * *} \\
(0.037)\end{array}$ & $\begin{array}{c}0.108^{* * *} \\
(0.037)\end{array}$ & $\begin{array}{c}0.106^{* * *} \\
(0.037)\end{array}$ & $\begin{array}{c}0.106^{* * *} \\
(0.037)\end{array}$ \\
\hline Current educational level & $\begin{array}{c}-0.172^{\star *} \\
(0.085)\end{array}$ & $\begin{array}{l}-.194^{* *} \\
(0.084)\end{array}$ & $\begin{array}{l}-.173^{* *} \\
(0.085)\end{array}$ & $\begin{array}{l}-.203^{* *} \\
(0.085)\end{array}$ & $\begin{array}{l}-.190^{* *} \\
(0.084)\end{array}$ & $\begin{array}{l}-.161^{*} \\
(0.085)\end{array}$ & $\begin{array}{l}-.178^{* *} \\
(0.085)\end{array}$ \\
\hline \multicolumn{8}{|l|}{ Independent variable } \\
\hline Political trust & $\begin{array}{c}0.346^{* * *} \\
(0.076)\end{array}$ & & $\begin{array}{c}0.345^{* * *} \\
(0.076)\end{array}$ & & & & \\
\hline General trust & & $\begin{array}{c}0.026 \\
(0.071)\end{array}$ & $\begin{array}{c}0.022 \\
(0.072)\end{array}$ & & & & \\
\hline Special trust & & $\begin{array}{c}0.062 \\
(0.073)\end{array}$ & $\begin{array}{c}0.058 \\
(0.074)\end{array}$ & & & & \\
\hline $\begin{array}{l}\text { Party committee and } \\
\text { government of centre }\end{array}$ & & & & $\begin{array}{l}0.492^{* * *} \\
(0.117)\end{array}$ & & & \\
\hline $\begin{array}{l}\text { Party committee and } \\
\text { government of province }\end{array}$ & & & & & $\begin{array}{l}0.249^{* *} \\
(0.117)\end{array}$ & & \\
\hline $\begin{array}{l}\text { Party committee and } \\
\text { government of county }\end{array}$ & & & & & & $\begin{array}{c}0.409^{* * *} \\
(0.108)\end{array}$ & \\
\hline $\begin{array}{l}\text { Party committee and } \\
\text { government of township }\end{array}$ & & & & & & & $\begin{array}{c}0.434^{* * *} \\
(0.095)\end{array}$ \\
\hline Constant & $\begin{array}{l}1.906^{\star * *} \\
(0.722)\end{array}$ & $\begin{array}{c}-2.347^{\star * *} \\
(0.711)\end{array}$ & $\begin{array}{c}-1.949^{* * *} \\
(0.724)\end{array}$ & $\begin{array}{c}-3.860^{* * *} \\
(0.812)\end{array}$ & $\begin{array}{l}-2.970^{* * *} \\
(0.779)\end{array}$ & $\begin{array}{c}-3.325^{\star \star \star} \\
(0.767)\end{array}$ & $\begin{array}{c}-3.162^{* * *} \\
(0.743)\end{array}$ \\
\hline Cox \& Snell $\mathrm{R}^{2}$ & 0.141 & 0.132 & 0.142 & 0.138 & 0.126 & 0.135 & 0.141 \\
\hline Nagelkerke $\mathrm{R}^{2}$ & 0.193 & 0.168 & 0.194 & 0.189 & 0.173 & 0.185 & 0.193 \\
\hline
\end{tabular}

Note: The numbers in the table are rounded off. The number in parentheses is the standard error level of significance: ${ }^{* * *} \mathrm{P}<0.01,0.01<* * * \mathrm{P}<0.05,0.05<$ $\mathrm{P}^{*}<0.1$.

$0.492,0.249,0.409$, and 0.434 , respectively, indicating that the more the villagers trust each level of government, the more they tend to participate in political activities. As can be seen from the table, the trust of the central government and the township government has a greater influence on the villagers' political participation, while the provincial government's influence on trust is relatively small.

It can be seen that the general political trust of the villagers has a positive effect on political participation, and that the trust of the government at the four 
levels of the central government, provinces, counties, and townships will affect their political participation. However, as far as social trust is concerned, general trust and special trust are not significant for the villagers' political participation.

\section{Conclusions and Discussions}

As the two dimensions of trust, political trust and social trust have all had a significant impact on the villagers' political participation. Which one has a greater impact? This study uses 974 data from the Survey of Rural Democracy and Governance in China to analyze this issue. The main conclusions and discussions are as follows:

First, there is a strong positive correlation between political trust and villagers' political participation. Political trust has significantly increased the possibility of villagers' political participation. Huntington suggested that the promotion of political trust by individual citizens or social groups contributes to the political participation of the whole country [22]. Political trust can enhance villagers' evaluation of government activities. Villagers are more likely to believe the performance of government activities and believe that their political participation will have an impact on the political process. Political trust is a major driving force for villagers' political participation. Therefore, the villagers' political trust should be raised to effectively promote the villagers' political participation, promote the development of grassroots democracy and village self-government. First of all, as far as the ruling party is concerned, we must uphold the concept of fairness and justice, continuously improve the level of governance and the ability to govern, and can accommodate different opinions and opinions. The grass-roots government workers and village committees most frequently contacted by villagers must establish their own image, establish a good relationship between the masses and the villagers, break the barriers of rural interests, and fairly handle village affairs, and effectively do a good job in grassroots governance. Second, in terms of monitoring mechanisms, reasonable and effective allocation of power and effective supervision, rural society is an acquaintance society. It also needs the supervision and restriction of power, guarantees the legalization of the political input of rural strong and weak groups, protects the fundamental interests of vulnerable groups, and promotes the healthy operation of the rural political system. Third, as far as government functions are concerned, the government must further improve its ability to enhance its administrative functions. As the lagging area of economic development in China's vast rural areas, under the dual urban-rural system, economic and cultural aspects are even more backward. Therefore, at the central level, more preferential agricultural policies should be introduced to break the current dual system that restricts rural development. The grass-roots government and village committees must effectively fulfill their functions and meet the growing cultural and material needs of the villagers in order to obtain Villagers' trust and support.

Second, there is no statistical significance between social trust and villagers' 
political participation. Whether it is general trust or special trust has no significant impact on the villagers' political participation. The theory of social capital holds that horizontal interpersonal communication can increase interpersonal trust, which in turn makes it easier for people and people to form cooperative relationships. This makes it easier to form mass organizations and organizers are more willing to participate in political activities. This shows that general trust factors have promoted citizens' political participation to a certain extent. However, why the general trust does not have a significant impact on the villagers' political participation in this study needs further study.

Third, the villagers' trust in party committees and governments at all levels has a significant influence on political participation. The more the villagers who are trusted by the government are more willing to participate in political activities such as elections, the results of this analysis are consistent with the conclusions of some domestic scholars. However, the existing research focuses on political trust mainly at the level of township party committees and governments, and believes that the positive correlation between the two exists is determined by China's current political system and "pressure-type" local governance mechanism. There is a lack of comparison of the level of trust among governments at all levels and this study found that the villagers' level of political trust at all levels will affect political participation. In other words, it's not just the nearest township government to the villagers that has a clear role in political participation. This may be because with the rapid development of the media and the Internet, the vast rural areas have obviously increased their awareness of the policies and government activities promulgated by the senior and middle-level governments, and the flow of information between the governments at all levels and villagers has also been strengthened. The hard-to-reach behaviors and policies of high-level governments can also subjectively assess the performance of villagers, which in turn affects the villagers' political participation. In all levels of government, the trust level of the government at the first and last tiers of the central government and townships explains the political participation of the villagers. This may be because the villagers visualize the central government as a state, and the state directly issues related policies concerning agriculture, rural areas, and agriculture. Guide the direction of rural development, so the villagers' trust in the central government has a greater influence on their participation in political activities. Compared with other levels of government, township governments, as the executors of rural public policies, are the most basic governments that deal directly with the villagers and govern in villages. There is an important position among them, so the villagers' trust in the township government explains the political participation of the villagers.

Of course, there are still shortcomings in this study, only "whether to participate in the election of village committee" as an indicator to measure villagers' political participation, not other forms of political participation, the conclusion is bound to deviate. In addition, this paper based on the analysis of the database, only based on statistical interpretation of the research system rather than the ex- 
planation of causal mechanisms. In reality, the relationship between political trust, social trust and political participation is complex. It is difficult to get a true conclusion only in quantitative analysis, so fieldwork and other qualitative research methods are needed for further study.

\section{References}

[1] Wu, L.Q. (2009) The Role of Political Participation and Democratic Supervision in the Network Environment. Chinese Collective Economy, No. 10S, 193-194.

[2] Hu, R., Hu, K. and Wen, Y.Y. (2011) Social Capital, Government Performance and Urban Residents' Trust in Government. Sociological research, No. 1, 96-117.

[3] Easton, D. (1977) A System Analysis of Political Life. British Journal of Sociology, 61, 104-117.

[4] Miller, A.H. (1974) Political Issues and Trust in Government: 1964-1970. American Political Science Review, 68, 951-972. https://doi.org/10.2307/1959140

[5] Chen, P. (2014) Theoretical Construction of Political Trust: From Connotation to Function. Guizhou Social Sciences, No. 10, 17-20.

[6] Mishler, W. and Rose, R. (2001) What Are the Origins of Political Trust? Testing Institutional and Cultural Theories in Post-Communist Societies. Comparative Political Studies, 34, 30-62. https://doi.org/10.1177/0010414001034001002

[7] Norris, P. (1999) Critical Citizens: Global Support for Democracy Government. Oxford University Press, Oxford, 9-10. https://doi.org/10.1093/0198295685.001.0001

[8] Gamson, W. (1968) Power and Discontent. Dorsey Press, Homewood, IL.

[9] Sun, X., Xu, Z.G., Tao, R., et al. (2007) Political Trust, Social Capital and Villagers' Election Participation-Empirical Analysis Based on National Representative Sample Survey. Sociological Studies, 4, 165-1877.

[10] Zheng, J.J. (2013) The Relationship between Political Trust, Social Justice and Political Participation-An Empirical Analysis Based on 625 Chinese Participants. Political Studies, 6, 61-74.

[11] Fu, Y.H. (2014) The Multivariate Linear Regression Was Used to Analyze and Predict the Farmers' Political Participation, Which Was Based on 3993 Questionnaires from 272 Villages in China. Journal of Chinese Academy of Governance, 2, 54-59.

[12] Hu, D.F. (2010) Villagers' Political Trust and Its Influence on Village Election Participation-An Empirical Study Based on the investigation of p Village in Huizhou City, Guangdong Province. Journal of Jinan (Philosophy and Social Sciences Edition), 32, 156-162.

[13] Shi, T. (1999) Voting and Nonvoting in China: Voting Behavior in Plebiscitary and Limited-Choice Elections. Journal of Politics, 61, 1115-1139. https://doi.org/10.2307/2647556

[14] Patnam, R. and Lai, H.R. (2015) Making Democracy Work: Civic Traditions in Modern Italy. Renmin University Press, Beijing.

[15] Uslaner, E. (2002) The Moral Foundations of Trust. Cambridge University Press, Cambridge. https://doi.org/10.1017/CBO9780511614934

[16] Rotter, J. (1967) A New Scale for the Measurement of Interpersonal Trust. Journal of Personality, 35, 651-665. https://doi.org/10.1111/j.1467-6494.1967.tb01454.x

[17] Edlin, A.S., Gelman, A. and Kaplan, N. (2007) Voting as a Rational Choice: Why and How People Vote to Improve the Well-Being of Others. Rationality \& Society, 
1, 293-314. https://doi.org/10.1177/1043463107077384

[18] Xing, C.B. and Luo, C.L. (2011) Social Trust and Political Participation: The Voting Behavior of the People's Congress Deputies at the Grassroots Level in Cities and Towns. World Economic Literature, 17-28.

[19] Tang, W.F. (2008) Chinese Opinions and Civil Society. SunYat-sen University Press.

[20] Li, L. (2004) Political Trust in Rural China. Modern China, 30, 228-258. https://doi.org/10.1177/0097700403261824

[21] Bahry, D. and Silver, B.D. (1990) Soviet Citizen Participation on the Eve of Democratization. American Political Science Review, 84, 821-847. https://doi.org/10.2307/1962768

[22] Huntington, S.P. and Nelson, J.M. (1989) Difficult to Choose: Political Participation of Developing Countries. Huaxia Publishing House. 